\title{
On the Naming of Arizona
}

\author{
WILLIAM A. DOUGLASS
}

$\mathrm{T}_{\mathrm{H}}$ HE ORIGINS OF THE NAMES of all but a few of the 50 United States are well known. Of the difficult cases, that of Arizona probably poses the greatest problem. In a relatively recent article, ${ }^{1}$ Adlai Feather analyzed in detail the process whereby the forty-eighth state of the Union acquired its designation. He declined to speculate on the etymology of the word, simply noting that it originally referred to ". . . the Arizona mine. . .situated on an arroyo of that name." 2

Reference to the mine's existence was provided in an account published in 1754 by the Jesuit priest José de Ortega. ${ }^{3}$ Almost a century later (1850), José Francisco Velasco published a book in Mexico about the Sonora region. ${ }^{4}$ Feather notes:

Its appearance created a furore among prospectors, miners, promoters, and the general public. Since it was intended to draw attention to the conditions and resources of Sonora, including a great part of the Gadsden Purchase, he devoted one chapter to the minerals of the state in which was [sic] included accounts of several notable discoveries of rich placer deposits; fields where a man with only his hands as tools or, at most, a shovel and pan might become wealthy in a few days. Especially attractive was a site [Arisona] where silver nuggets of enormous size were found in loose soil. This location lay deep in Apache territory, there were no mining officials on the ground and the men who flocked to the place simply excavated without order or system, found what they could and abandoned the place when the Apaches began to gather. ${ }^{5}$

\footnotetext{
'Adlai Feather, "Origin of the Name Arizona," New Mexico Historical Review, 39:2 (1964), 89-100.

${ }^{2}$ Ibid., p. 91.

${ }^{3}$ José de Ortega, Apostólicos afanes de la Compañia de Jesús escritos por un padre de la misma sagrada religión de su provincia de México, 3rd ed. (México, D.F.: Ed. Layac, 1944).

${ }^{4}$ José Francisco Velasco, Noticias estadísticas del estado de Sonora, acompañadas de ligeras reflecsiones, deducidas de algunos documentos y conocimientos prácticos (México, D.F.: Impr. de I. Cumplido, 1850).

${ }^{5}$ Feather, op. cit., p. 97.
} 
It is clear that Velasco's description of Sonoran mineral wealth, in the form of horn silver deposits of extraordinary value, was based upon Ortega's report. Both accounts are in substantial agreement regarding the fact that the deposits were of a surface variety, containing large nuggets of almost pure silver. Both agree a settlement was established that was subsequently abandoned due to the hostility of the Apaches, depletion of the mineral, high transportation costs, and an attempt by the royal authorities to secure complete control of production. ${ }^{6}$

American prospectors and adventurers were among those influenced by the Valasco work. ${ }^{7}$ Chief among these were Charles D. Poston who became one of the region's major promoters. Poston later contended that it was he who suggested to James A. Lucas that the new territory be christened Arizona. ${ }^{8}$ Therefore, while Feather details how Arizona acquired its name, he does not consider the original derivation of the term. Etymologists interested in this question have naturally looked to the region's Hispanic and Indian heritages for their clues, and at times the results have been startling. Writing in 1889 Hubert Howe Bancroft notes:

Such guesses as are extant, founded on the native tongues, offer only the barest possibility of partial and accidental accuracy; while similar derivations from the Spanish are extremely absurd. [fn] Of the former class may be mentioned the following: ari, 'maiden,' and zon, 'valley,' from the Pima; ara and sunea, or urnia, the sun's beloved, from the Mojave; ari, 'few,' and zoni 'fountains;' ari, 'beautiful,' and the Spanish zona: Arizuma, Aztec for 'silver-bearing;' Arezuma, an Aztec queen; Arizunna, 'the beautiful;' Arizonia, the maiden queen or goddess who by immaculate conception gave being to the Zuñi Indians; also the meaning 'little creek' is given. Of the second class we may note arrezafe, a country covered with brush-wood; árida zona, or an arid zone or region; and narizona, a big-nosed woman!9

\section{Bancroft concludes:}

Arizona, probably Arizonac in its original form, was the native and probably Pima name of the place-of a hill, valley, stream, or some other

\footnotetext{
${ }^{6}$ Ibid., pp. 91-97.

${ }^{7}$ Parts of it were subsequently translated into English (1861) by William F. Nye, stimulating a silver rush to the American Southwest (Feather, p. 100).

${ }^{8}$ Feather, op. cit., pp. 91-97.

${ }^{9}$ Hubert Howe Bancroft, The Works of Hubert Howe Bancroft. Vol. 17: History of Arizona and New Mexico, 1530-1888 (San Francisco: The History Co., Publishers, 1889), pp. 520-21.
} 
local feature-just south of the modern boundary, in the mountains still so called, on the headwaters of the stream flowing past Saric, where the famous Planchas de Plata mine was discovered in the middle of the eighteenth century, the name being first known to the Spaniards in that connection and being applied to the mining camp, or real de minas. ${ }^{10}$

Subsequently, speculation narrowed down to two possibilities-the Spanish árida zona or "arid zone," which is still suggested in some standard place-names works, ${ }^{11}$ and the Pima-Papago theory first posited by Bancroft. As for the former there is little reason to give it much credence. The juxtaposing of the Spanish terms makes for good direct translation into English, but is ungrammatical in the original. Had such elisioning been the source, the name of the state would more likely be "Zonarida" than "Arizona."

Conversely, the Pima-Papago theory may not be discounted out of hand, and has received the greatest attention and acceptance. In fact, by the turn of the present century interested scholars were no longer questioning whether or not Arizonac was a Pima-Papago term but rather its precise meaning. Samuel Hughes, for example, contended that ari-sonac meant "place of chastisement." ${ }^{12}$ Frederick W. Hodge, on the other hand, in the Handbook of American Indians North of Mexico (1907), translated it as "small springs" or "few springs." ${ }^{13} \mathrm{He}$ was supported in this interpretation by M. P. Freeman and Issac D. Smith. ${ }^{14}$ By 1916 the Arizona historian McClintock pronounced the debate over by stating, "The burden of proof sustains Doctor Freeman, Mr. Hodge, and Mr. Smith. All would indicate that little reason exists for further research along this line." 15 Subsequently, popular writers have accepted this interpretation, ${ }^{16}$ and in Arizona Place Names, the

\footnotetext{
${ }^{10}$ Ibid., p. 520.

${ }^{11}$ E.g., Henry Gannett, Place Names in the United States, 2nd ed. (Baltimore: Genealogical Publishing Co., Inc., 1973), p. 28; Kelsie B. Harder, Illustrated Dictionary of Place Names: United States and Canada (New York: Van Nostrand Reinhold Co., 1976), p. 19.

${ }^{12}$ Cited in James McClintock, Arizona: The Youngest State (Chicago: S.J. Clarke Publishing Co., 1916), p. 1.

${ }^{13}$ Frederick Webb Hodge, "Arizonac," in Handbook of American Indians North of Mexico I, Frederick Webb Hodge, ed., Bulletin 30, Bureau of American Ethnology, Smithsonian Institution (Washington, D.C.: Government Printing Office, 1907), p. 87.

${ }^{14}$ Cited in McClintock, op. cit., p. 3.

${ }^{15} \mathrm{Ibid}$.

${ }^{16}$ Cf. Norman G. Wallace, "Arizonac, A Tale of the Country which Gave Arizona Its Name," Arizona Highways 9:13 (1933), pp. 3-5, 23-24; Roscoe G. Willson, "The Origin of Arizona's Name," Arizona Highways 31:3 (1955), pp. 2-5; and Don Dedera, "Inside Arizona, Outside," Outdoor Arizona (August, 1978).
} 
standard reference work, we find: "The word arizonac is derived from Papago Indian words, ali ('small') and shonak ('place of the spring'), or 'place of the small spring.", 17

There are, however, several problems with accepting the PimaPapago theory uncritically. On the one hand, there is the conflicting internal evidence of the Indian language itself. The Saxton and Saxton English to Papago/Pima dictionary renders "little springs" as $\mathrm{Al}$ Shoshon rather than Arizonac or Alishonak (while at the same time indicating that it is the form giving rise to the modern "Arizona"). ${ }^{18}$ There are conceivable ways of modifying this term to render alishonak, but it is at least worth noting that some such process must be demonstrated. While it might first appear that the -ac of arizonac is tellingly absent from alshoshon, in fact a feature of Pima-Papago grammar may well be capable of supplying it. The language utilizes the suffixes -dag and $-g$ (pronounced $-d a k$ and $-k$ ) added to noun stems to mean "sphere or domain of." 19 Alshonshondag might therefore be rendered as "the sphere or domain of the little springs." However, while it is possible to envision a progression from alshoshondag (or some such term) to arizonac, it is unlikely that the latter ever existed as an acceptable colloquial form in Pima-Papago.

On the other hand there are questions concerning the contact situation between the Indians and Spaniards. If the Pima-Papago term was something like Alishonak or Alshoshondag there is the problem of demonstrating how the Spaniards transformed the place-name into Arizona. One linguistic rule of thumb is that the Spaniards were likely to retain those aspects of the form phonetically acceptable in Spanish, and modify or reject those that were not. In an Alishonak $\rightarrow$ Arizona transformation there are three key changes. The $-l$ - is converted to $-r$-, the $-s h$ - to $-z$ - and the final $-k$ - is dropped.

The first, or $-l$ - to $-r$ - change, seems at first the most difficult to explain since ali is phonetically euphemonious in Spanish (e.g., alimento, alianza) and the Spaniards had ample Iberian peninsula precedent of utilizing it when borrowing certain Arab forms (e.g., aliacán, alifafe, alijar, alimara). Why, then, is the name of the state not

\footnotetext{
${ }^{17}$ William Croft Barnes, Arizona Place Names, Revised and enlarged by Byrd H. Granger (Tucson: University of Arizona Press, 1960), p. xv.

${ }^{18}$ Dean Saxton and Lucille Saxton, Dictionary: Papago and Pima to English, O'odham-Milgahn: English to Papago and Pima (Tucson: University of Arizona Press, 1969), p. 39.

${ }^{19} \mathrm{Ibid}$., p. 142.
} 
"Alizona"? Again the Indian language may hold the key since the $l$ in Pima-Papago is flapped, which somewhat approximates it phonetically to the $r$ sound. ${ }^{20}$ As for the second and third changes there is little problem. Since Spanish does not possess an sh sound the $z$ is an acceptable and logical substitute. As for the final $-k$, again such an element is foreign to the Spanish ear, and might simply have been dropped by the Spaniards. ${ }^{21}$

In sum, to accept the Pima-Papago theory regarding the origins of the name Arizona is to invoke certain, but not insuperable, problems both with respect to the internal evidence of the Indian language and adoption of the term by the Spaniards. This notwithstanding, it may well be that the Pima-Papago theory is correct. However, given the above discussion, and the historical evidence that is to follow, it is more likely that the term "Arizona" is of neither Indian or Spanish origin, but rather derives from the Basque language.

To appreciate why this may have been the case it is necessary to consider the nature of "Hispanic" settlement of present-day northern Mexico and the American southwest. Too frequently historians of Latin America have interpreted the region's past from a Castile-centric perspective, thereby glossing over Iberian cultural distinctions of considerable ethnic importance. On the eve of the discovery of the Americas, the Basques were Spain's mariners and mercenaries par excellence. As such they were from the outset heavily involved in Spain's New World colonial venture. By one estimate, between the years 1520 and 1580 fully 80 percent of the vessels on the American run were either Basque-manned and/or owned by Basque commercial interests. ${ }^{22}$ Temporally, throughout the colonial era and, geographically, in all of the colonies, Basques played prominent roles as merchants, soldiers, administrators, and ecclesiastics. ${ }^{23}$ However, nowhere was this more the case than in the northern reaches of Nueva España during the sixteenth century.

In 1527 the Basque Juan de Zumárraga was appointed bishop of Mexico City and quickly surrounded himself with relatives and fellow townsmen by recruiting colonists from his native region of Durango,

\footnotetext{
${ }^{20}$ Kenneth Locke Hale, “A Papago Grammar,” Diss. Indiana University, 1959, p. 15.

${ }^{21}$ Barnes, op. cit., p. xv.

${ }^{22}$ John Lynch, Spain Under the Hapsburgs, Vol. I: Empire and Absolutism (1516-1598) (New York: Oxford University Press, 1964), p. 165.

${ }^{23}$ William A. Douglass and Jon Bilbao, Amerikanuak: Basques in the New World (Reno: University of Nevada Press, 1975), Chap. 2.
} 
Vizcaya. ${ }^{24}$ They, as well as other Basques such as Cristóbal de Oñate, who arrived in Mexico City in 1524, were to spearhead the drive northward in search of the fabled treasures of Quivira. Cristóbal and his brother Juan, in the service of Nuño de Guzmán (a non-Basque), were charged with controlling the Indians of present-day Jalisco, founding in the process the city of Guadalajara. They were rewarded with large encomiendas but were forced to abandon the area by Indian uprisings. Cristóbal later returned with an expeditionary force that contained a major contingent of Basques. Most of them stayed on in Jalisco and formed the backbone of future expeditions to the north.

Among Oñate's forces was Juan de Tolosa, a relative of Bishop Zumárraga. Commanding his own expeditionary force, Tolosa discovered silver deposits and founded the city of Zacatecas, thereby initiating one of the most important mining endeavors in New World history. Diego de Ibarra, another relative of Zumárraga, was likewise involved and is regarded as co-founder of the city.

Cristóbal de Oñate, Juan de Tolosa and Diego Ibarra all made fortunes at Zacatecas and each attracted to his side relatives from the Basque country. The new arrivals were obsessed with the idea of making mineral discoveries of their own. According to the historian Robert C. West, "Beginning with the famous Zacatecas discovery in 1546, Basque miners rapidly overran the foothills northwestward, founding numerous reales, such as San Martín, Fresnillo, Indé, and Santa Barbara." 25 Blakewell notes that Basque families in Zacatecas were relatively few in numbers but influential. He concludes, "Above all, Basques were great explorers; and Zacatecas the source of finance for their expeditions and the base from which they set out." 26

At the same time Basques continued to play a central role in official attempts to explore the northern reaches of Nueva España. Diego de Ibarra married the sister of the Virrey (or highest official) Velasco and acquired from him the rights to explore and colonize beyond the northernmost limits of Spanish control. However, the elderly Diego decided to retire and therefore conferred the charge upon his nephew Francisco de Ibarra, commander of a contingent of troops at Zacatecas.

\footnotetext{
${ }^{24}$ See p. 110 of Vicente Lascurain, "Los Grandes Caudillos en la conquista de México," Boletín del Instituto Americano de Estudios Vascos (Buenos Aires), 7 (1956), 101-111, 219-238.

${ }^{25}$ Robert C. West, The Mining Community in Northern New Spain: The Parral Mining District, Ibero-Americana 30 (Berkeley and Los Angeles: The University of California Press, 1949), p. 6.

${ }^{26} \mathrm{P}$. J. Blakewell, Silver Mining and Society in Colonial Mexico, Zacatecas, 1546-1700 (Cambridge: Cambridge University Press, 1971), p. 13.
} 
From 1554 to 1566 Francisco explored the northern regions, founding the province of Nueva Vizcaya and its capital of Durango (named after what was either his birthplace or place of residence in the Basque country). Certain of his explorations or entradas took him as far north as present-day Sonora. According to the historian Obregón, Ibarra began his expeditions with "one hundred and seventy men. . the greater part of whom were Basques." 27 Ibarra served as governor of the region until his death in 1575 .

Meanwhile, in 1550 Cristóbal de Oñate fathered a son, Juan, who subsequently married the daughter of Juan de Tolosa. Utilizing his family's influence, in 1595 Juan de Oñate received a mandate to explore and colonize the present-day American Southwest. He founded a colony in New Mexico and, in 1601, penetrated as far north as southern Kansas. The New Mexico colony, faced with hostile Indians, failed. However, Oñate organized a second expedition and established a permanent settlement. In 1604 he explored Arizona and the lower Colorado River area, arriving at the Pacific on the coast of Baja California. In 1608 Onate, disillusioned, resigned as governor of New Mexico. ${ }^{28}$

Thus ended two generations of colonial expansion into northern Mexico and the southwestern United States in which Basque leadership, capital and manpower carried the brunt of the effort. This expansion left in its wake a society whose economy included numerous Basque hacendados and mine owners, and whose officialdom was heavy with Basque administrators, soldiers and clerics. That much of this effort was consciously and collectively Basque is reflected in the naming of a part of the region Nueva Vizcaya and its capital Durango, the crowning toponymic monument to Basque efforts in the New World.

During the seventeenth and early eighteenth centuries, the chronicles of the region continue to reflect a considerable Basque presence. The occurrence of Basque-surnamed individuals among the ranks of the missionaries, administrators, and military officials was far out of proportion to the group's percentage within Spain's Iberian population and its New World colonial contingent. We can therefore say that Basques played a major role in the exploration and colonization of

\footnotetext{
${ }^{27}$ Quoted in J. Lloyd Mecham, Francisco de Ibarra and Nueva Vizcaya (Durham: Duke University Press, 1927), pp. 121-22.

${ }^{28}$ Lascurain, op. cit., pp. 229-30.
} 
present-day northern Mexico and the American Southwest, motivated primarily by the search for precious metals.

However, of particular interest to the present argument is the extent to which Basques were involved in the silver excitement at Arizonac. In order to render judgment it is necessary first to consider the sparse and somewhat contradictory evidence regarding the founding of the Real de Arizonac, and especially the question of whether or not the Real was itself the site of the major silver discovery.

The historian Francisco R. Almada, in his work Diccionario de historia, geografía y biografia sonorenses, notes that the Real de Arizonac was founded in the year 1730 by the region's Alcalde Mayor, Gabriel de Prudhon Heider Beltrán y Múgica, who established a mining district after being shown the site by an Indian. ${ }^{29}$ In 1733 Prudhon published a map of Sonora on which he claims to be the founder of the Real, while providing the first cartographic evidence of its location. ${ }^{30}$ Almada believes that this was, indeed, the fabled Arizonac silver strike and that it was Prudhon who subsequently came into conflict with his successor as Alcalde Mayor, Juan Bautista de Anza. Reference is to the fact that the hornsilver deposits were so pure as to resemble refined metal. After an investigation Anza concluded that buried treasure rather than natural ore was at issue, in which case the king's share should be one-half rather than the usual 20 percent levied on the production of mines. Anza confiscated much of the wealth and thereby triggered lengthy litigation. ${ }^{31}$

From the resulting testimony it is clear that Prudhon's original strike was not at issue, nor was he a principal to the developments. Rather, the focus was upon a new site which, in a letter ${ }^{32}$ dated January 7, 1737 and directed to the Bishop of Puebla de los Angeles, Anza located ". . . between the Mission of Guebabi and the Rancheria of Arissona" (emphasis supplied). The letter states that the discovery was made ". . . at the end of October of the past year." Anza asked three priests,

\footnotetext{
${ }^{29}$ Francisco R. Almada, Diccionario de historia, geografia y biografía sonorenses (Chihuahua, 1952), p. 79.

${ }^{30}$ Miguel Othón de Mendizábal, Obras Completas III (México, D.F., 1946), opposite p. 42.

${ }^{31}$ For full treatment of the developments cf. Patricia Roche Herring, "The Silver of El Real de Arisonac," Arizona and the West, 20:3 (1978), 245-58.

${ }^{32}$ AGI, UAL, I, 2 (AGI, UAL refers to a seven volume manuscript collection of Documents Relevant to the History of the Southwest During Spanish Domination, 1736-1795 which are typed copies of originals in the Archivo General de Indias [AGI], Seville, Spain. The collection is located in the special collections library of the University of Arizona Library [UAL], Tucson.)
} 
Joseph Toral, Christoval Cañas and Juan de Echagoyen, who were visiting missions in the region to look into the situation and report back to him.

In a letter to the Virrey, dated July 13, 1757, Joseph de Mesa claimed that he and his partner Francisco Longoria made the original strike. ${ }^{33}$ There was a rival interpretation in the proceedings, however, since Anza notes that the discovery was made by an Indian, Yaqui Antonio, "... .with the intervention of. .." Bernardo de Urrea, Anza's lieutenant sent to investigate rumors of the strike. ${ }^{34}$ Irrespective of whether Mesa or Urrea was the European instrumental in the discovery and development of the new mining district, it seems evident that it should not be confused with Prudhon's earlier founding of the Real de Arizonac.

If the events are analyzed from a Basque ethnic standpoint, the results are striking. Gabriel Prudhon was of Basque descent on his maternal side. ${ }^{35}$ Juan Bautista de Anza was a European-born Basque who prior to becoming Alcalde Mayor of Sonora settled in the mining Real of Tetuachi in the municipality of Arizpe. ${ }^{36}$ Though seldom employed in published accounts the full name of Tetuachi was Real de Nuestra Señora de Aranzazu de Tetuachi. ${ }^{37}$ The sanctuary of the Virgen of Aranzazu is a major religious shrine in the Basque province of Guipúzcoa, and site of the major Franciscan monastery in the Basque area. The monastery produced many of the friars for the Franciscan New World missions. The Real of Tetuachi was founded in $1719,{ }^{38}$ or little more than a decade before the Arizonac excitement. The visitador Juan de Echagoyen was a Basque.

Anza clearly drew his immediate subordinates from the ranks of his fellow ethnics. In his January 7, 1737 report he notes that the preceding August he dispatched Captain Francisco de Mendizabal to castigate the

\footnotetext{
${ }^{33}$ AGI, UAL, I, Mesa to the Virrey, p. 1.

${ }^{34}$ AGI, UAL, II, 19-20, 29.

${ }^{35}$ Jacinto Suarez, Diccionario biográfico vasco-mexicano, n.d.-in manuscript collection, Basque Studies Program Library, University of Nevada, Reno.

${ }^{36}$ Arizpe, founded as a mission in 1646 (Diccionario Porrúa. Historia biografía, y geografía, de México, 3rd ed. [México, D.F.: Ed. Porrúa, S. A., 1970], p. 141) seems clearly to have been named after a Basque as it is a common Basque surname. Suarez notes that there was a visitador in the missions of Sinaloa, named Arizpe, who may well have been the inspiration for the name. This interpretation notwithstanding, Molina suggests an Indian etymology in which Arizpe translates as "the place of the brave ants" (Flavio Molina Molina, Nombres indigenas de Sonora y su traducción al español [Hermosillo, 1972], p. 11).
}

${ }^{37}$ AGI, UAL, II, 20.

${ }^{38}$ Almada, op. cit., p. 786. 
Apaches for their raiding. ${ }^{39}$ Bernardo de Urrea, Anza's lieutenant, born about 1710 in Culiacán, Sinaloa, was of Basque parentage..$^{40}$

When Anza issued his confiscation order Urrea was forced to turn over silver of his own. He then travelled about the immediate vicinity commandeering the treasure of others. In Arizonac itself he found considerable silver in the house of Nicolas Alfonso de Ochoa. ${ }^{41}$ In the Real de San Antonio Metopore he received the silver of the merchant Luis de Mendivil. ${ }^{42}$ In the Real of Nuestra Señora de Aranzazu de Tetuachi he confiscated the silver of Agustín de Vildosola, who was the town's sergeant major. ${ }^{43}$ Vildosola called in his accountant, Blas de Gortazar, who declared that they had not mined the mineral but rather received it in payment of debts from Indians and blacks. ${ }^{44}$ When Anza ordered a second examination of the strike the mining expert Joseph Uzarraga was named one of the investigators. ${ }^{45}$ Again Ochoa, Mendivil, Vildosola, Gortazar, and Uzarraga were all Basques.

While the foregoing suggests considerable Basque involvement in the Arizonac mining boom it does little to establish the circumstances leading to the naming of the site. The records simply do not establish the derivation of the name. One possibility is that Gabriel Prudhon coopted something like the Pima-Papago name for the area as the designation of the new Real. However, it is equally possible that the toponym was provided by a native Basque speaker, and there are immediate etymological implications. A particularly appealing interpretation, and one that is consonant with the history of the area, is that the term derives from the Basque arri which means "rock or stone" and also signifies "ore," and ona which is Basque for "good, valuable." Consequently, arri ona would mean "the good (or valuable) rock (or ore)." Of further interest is the fact that arriz means "quality or property of rock or ore." Hence, arriz ona would designate "good mineral quality." This is not, however, a common Basque usage and is an unlikely candidate for originator of the modern term. One would expect a more colloquial form to give rise to a place-name.

\footnotetext{
${ }^{39} \mathrm{AGI}, \mathrm{UAL}, \mathrm{I}, 9$.

${ }^{40}$ Suarez.

${ }^{41}$ AGI, UAL, II, 32.

${ }^{42}$ AGI, UAL, II, 99.

${ }^{43}$ AGI, UAL, II, 92.

${ }^{44}$ AGI, UAL, II, 93.

${ }^{45}$ AGI, UAL, IV, 6, 14-21.
} 
Of greater possibility is the combination of arritza ("rocky place") and ona which together would translate as "the good (or valuable) rocky place." What better name for a mining district? The transformation from arritza ona to Arizona is direct and requires minimal explication. Lacking the $-t z$ - sound in his own language the monolingual Spanish chronicler would easily substitute the $-z-$. The $-a$ of arritza would readily merge with the $o$ of ona. The only stickler is the modification of - $r r$ - to $-r$-, since Spanish shares the trilled -rr-sound with Basque. The expected form would have therefore been Arrizona. While this raises a legitimate doubt, it should be noted that it is not an isolated example. Spanish sources in rendering Basque last names sometimes mistakenly spell Ibarra as Ibara or, conversely, Irigaray as Irrigaray.

With all of its historical attraction, however, the Basque mineral etymology may not, in fact, be the correct one. There is yet another possibility, and one which is phonetically the most elegant. Reference is to the fact that in Basque aritz means "oak tree." Hence aritz ona means "good oak." Aritzona to Arizona, of all the etymological transformations (both Pima-Papago and Basque) considered thus far is the most direct. Acceptance of this interpretation, however, requires situational justification. The problem might be stated in the form of two interrogatives. On the one hand why would the Arizonac area qualify for designation as "place of the good oak," while on the other, why would the Basques be so impressed with oaks were they to encounter them that they would underscore the fact toponymically? There is telling ecological and historical evidence on both scores.

Oak trees figure prominently in descriptions of the region around the site of Arisonac. Wallace depicts the area as one of "Craggy peaks and oak covered slopes. . ." 46 while Willson locates Arizonac in ". . .a beautiful little valley amongst oak and mesquite clad hills." ${ }^{47}$ It is clear from other sources that the area was not just characterized by the incidence of oak trees, but actually constituted the apogee of the occurrence of oaks on the North American continent. Trelease in his work The American Oaks states: “. . . by far the greatest variety in American oaks is found in the Mexican highlands and. . the western Sierra Madre Range is preeminent in this respect." 48 Map One is adapted

\footnotetext{
${ }^{46}$ Wallace, op. cit., p. 3.

${ }^{47}$ Willson, op. cit., p. 5.

${ }^{48}$ William Trelease, The American Oaks, Memoirs of the National Academy of Sciences, 20 (Washington, D.C.: Government Printing Office, 1924), p. 23.
} 
from Fowler and details the distribution of five types of oaks in southern Arizona and extreme northern Sonora (Quercus gambelli, Quercus turbinella, Quercus arizonica, Quercus emoryi and Quercus oblogifolia). ${ }^{49}$ Palynological evidence suggests that oak distributions in the area have remained relatively unchanged for the past 3,000-4,000 years. ${ }^{50}$ Map Two is adapted from Brand ${ }^{51}$ and traces the distribution of what the author depicts as an oak-agave-juniper vegetative zone in the Sonora-Sinaloa region (individual species undifferentiated).

A particularly interesting feature of Map One is that Quercus gambelli and Quercus turbinella are widely distributed over the area, but that Quercus arizonica, Quercus emoryi and Quercus oblogifolia are sympatric in the western part of their distribution, a point to which we will return. Quercus gambelli, or Gambel's scrub oak, and Quercus turbinella, or Scrublive oak, are of little value, and were scarcely utilized even in the region's aboriginal economies. ${ }^{52}$ Quercus gambelli usually occurs as a shrub and in thickets, but can attain a height of 50 feet in protected areas. ${ }^{53}$ Its only use is as a fuel source. ${ }^{54}$ Quercus turbinella constitutes part of the chaparral, usually growing as a shrub and attaining a maximum of 13 feet. ${ }^{55}$ The other species are, however, a different matter. Quercus arizonica, or Arizona white oak, attains a height of 60 feet with a trunk diameter of three feet. ${ }^{56}$ Quercus emoryi, Emory oak or Blackjack oak, grows as high as 50 feet. ${ }^{57}$ Quercus oblogifolia, or Mexican blue oak, attains 26 feet with a broadly spreading crown. ${ }^{58}$

It is clear that the first Europeans entered the area from the west. The coastal plain between the Gulf of California and the Sierra Madre

\footnotetext{
${ }^{49}$ Catherine S. Fowler, "Some Ecological Clues to Proto-Numic Homelands," in Great Basin Cultural Ecology, A Symposium, Don D. Fowler, ed., Desert Research Institute Publications in the Social Sciences, No. 8 (Reno: Desert Research Institute, University of Nevada System, 1972), p. 109.

${ }^{50} \mathrm{lbid}$.

${ }^{5}$ Donald D. Brand, "Notes to Accompany a Vegetative Map of Northwest Mexico," The University of New Mexico Bulletin, No. 280, Biological Series 4:4 (1930).

${ }^{52}$ Fowler, op. cit., p. 109.

${ }^{53}$ Thomas H. Kearney and Robert H. Peebles, Arizona Flora (Berkeley: University of California Press, 1964), p. 219.

${ }^{54}$ Richard Joseph Preston, North American Trees (Exclusive of Mexico and Tropical United States) (Ames: Iowa State College Press, 1948), p. 185.

${ }^{55}$ Kearney and Peebles, op. cit., p. 218.

${ }^{56} \mathrm{Ibid}$.

${ }^{57}$ Ibid., p. 219.

${ }^{58}$ Ibid., pp. 217-18.
} 

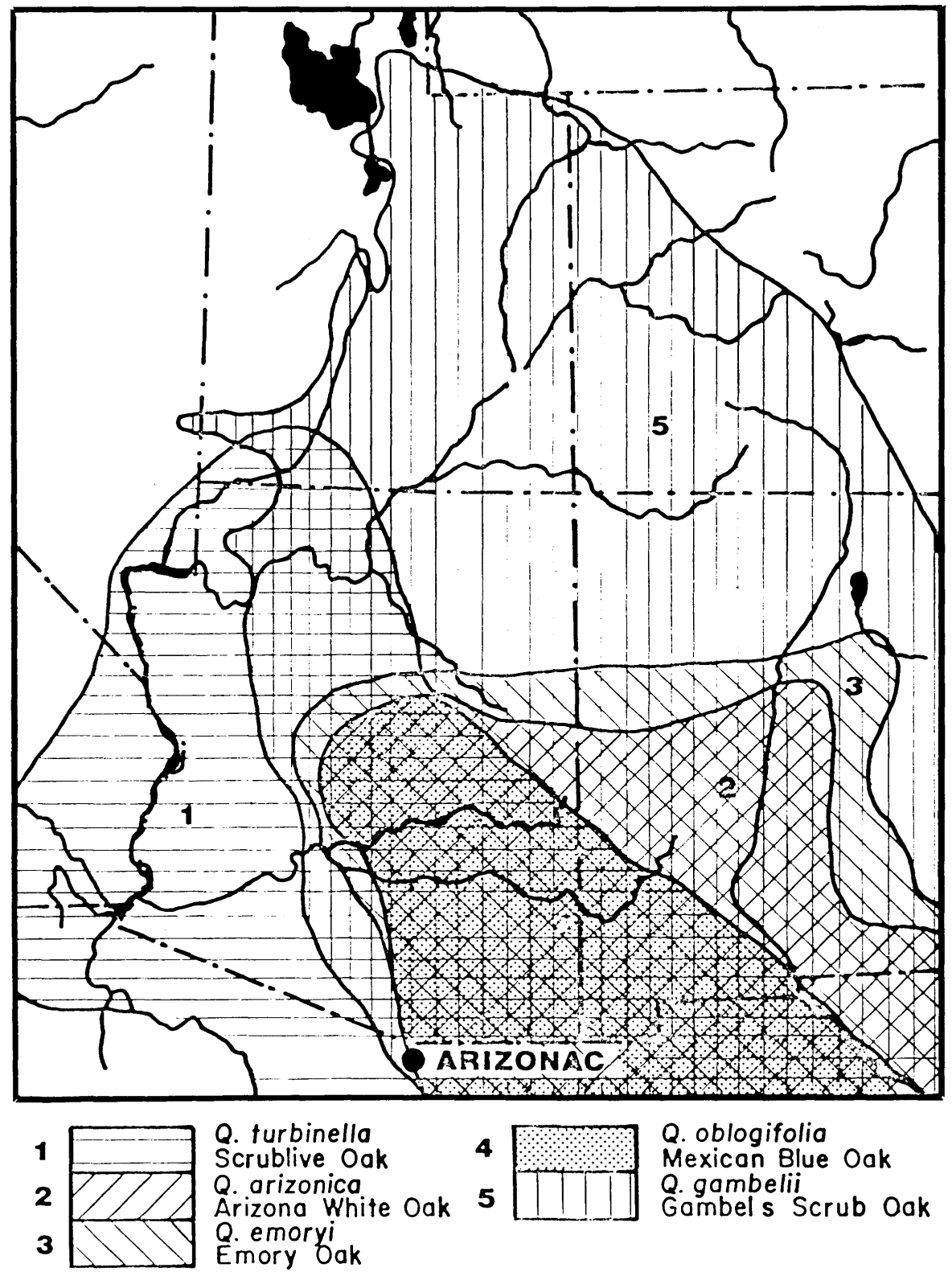

Q. turbinella Scrublive Oak Q. arizonica Arizona White Oak Q. emoryi Emory Oak

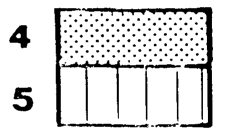

Q. oblogifolia Mexican Blue Oak Q. gambelii Gambel s Scrub Oak

\section{Map One. Oak Distributions in Southwestern United States}

Source: Catherine S. Fowler, "Some Ecological Clues to Proto-Numic Homelands," in Great Basin Cultural Ecology, A Symposium, Don D. Fowler, ed., Desert Research Institute Publications in the Social Sciences, No. 8 (Reno: Desert Research Institute, University of Nevada System, 1972). 


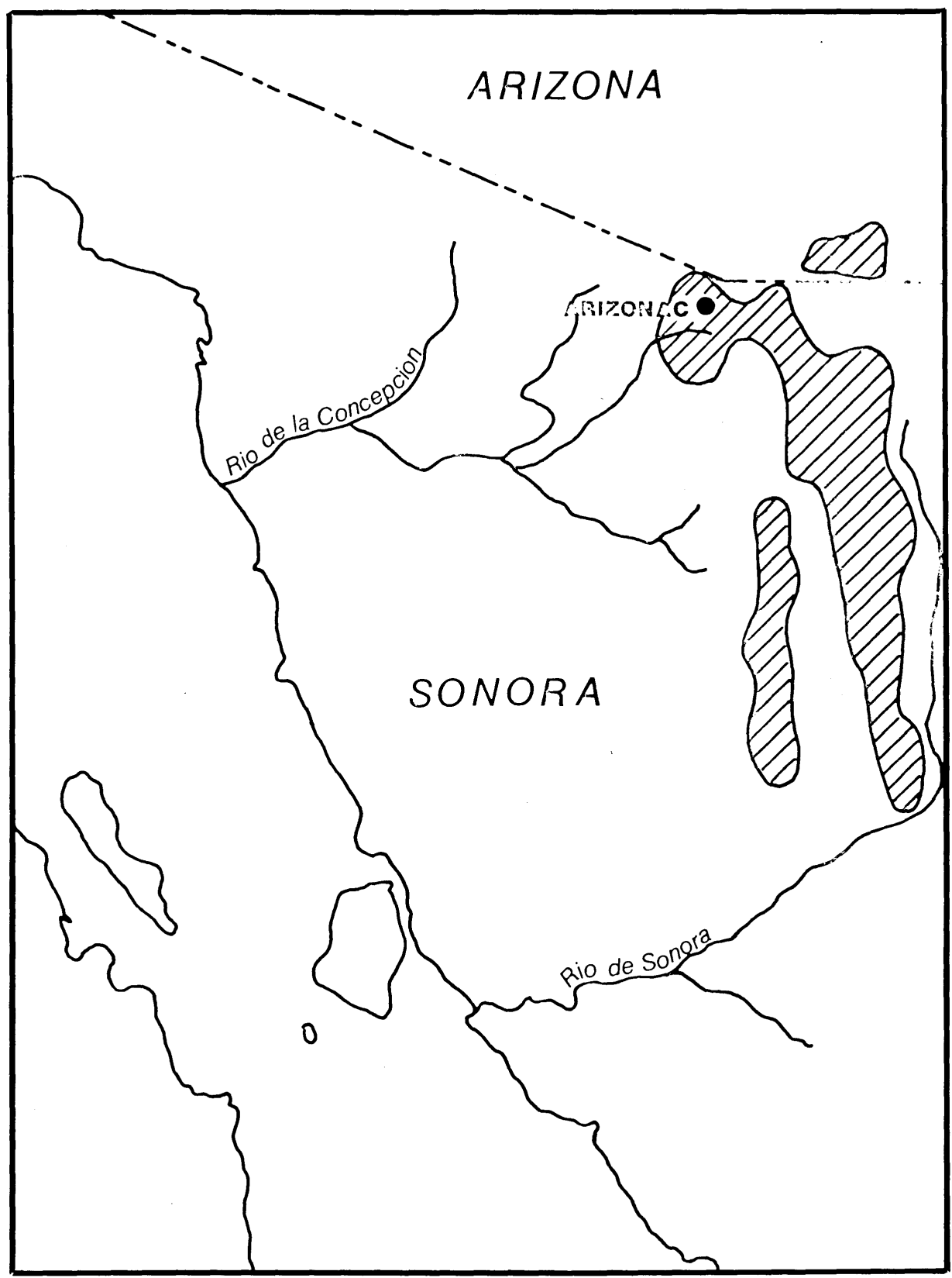

Map Two. Distribution of Oak, Agave and Juniper Forest in Northwestern Mexico

Source: Donald D. Brand, "Notes to Accompany a Vegetative Map of Northwest Mexico," The University of New Mexico Bulletin, No. 280, Biological Series 4:4 (1930). 
mountains was an early corridor of Spanish exploration and settlement. Fray Marcos de Niza, Coronado, and Francisco de Ibarra all used it in their northward forays. According to Wyllys, "Long before 1560 the cattlemen had great herds of cattle pastured in the Mayo and Yáqui valleys, and the more venturesome were taking their bestias on beyond, to the valley of the Rio Sonora. The miners, too, were exploring these valleys and settling in likely places. . . ." ${ }^{59} \mathrm{By}$ the early seventeenth century the Spanish had contracted peaceful agreements with the Yáquis, and missions had been established among the Mayo Indians. ${ }^{60}$ Throughout the century the Spaniards continued to penetrate northward into Pima-Papago territory. "To the west, in the lower Sonora valley, were the unreceptive Seris; to the east, in the Sierra Madre foothills, roved the marauding Apaches. . . ." ${ }^{61}$ However, the Europeans were able to operate rather freely within the Pima-Papago area. According to one source, "Although some groups of the Piman revolted against Spanish rule in 1695 and again in 1751, their record of relationships with non-Indians was largely that of allies against the Apache." ${ }^{2}$ Entering the area from the coastal plain the first Europeans would have crossed the westernmost limits of the ranges of Quercus arizonica, Quercus emoryi, and Quercus oblogifolia at just about the site of Arizonac.

According to our argument the area might have been named by a Basque(s) and there is ample reason to believe that the Basques, more than any other Iberian group, would have seen sensitized to the presence of "good or valuable oak." Of all the varieties of native vegetation in the western Pyrenean homeland, no other tree played a larger role in the economy. Practically every Basque farmstead had its privately owned tract of oak, chestnut and, possibly, beech forest. Every village had its communal woods made up largely of the same varieties. The acorns were an important food source for sheep, goats and pigs, and oak timber was the major source of material for housing. ${ }^{63}$

\footnotetext{
${ }^{59}$ Rufus Kay Wyllys, Pioneer Padre: The Life and Times of Eusebio Francisco Kino (Dallas, 1935), p. 69.

${ }^{60}$ Ibid.

${ }^{61}$ Ibid., p. 71.

${ }^{62}$ Bernard L. Fontana, "Piman Indians," in The Reader's Encyclopedia of the American West, Howard R. Lamar, ed. (New York: Thomas Y. Crowell Co., 1977), p. 938.

${ }^{63}$ The trees were so important that when near the turn of the present century the native stands of Pyrenean oaks and chestnuts were destroyed by disease, the Basques reseeded American oaks and Japanese chestnuts in their stead (Inozenzio Munita, Gure Mendi ta Oianak [Tolosa: Ed. Muguerza, 1952]).
} 
Just as importantly in most rural areas of the Basque country the fabrication of charcoal, primarily utilizing oak, was the major source of wage employment. ${ }^{64}$ The Basque country, with its extensive deposits of iron ore, was famed for its steel industry. However, the region lacked coal, and wood charcoal was the fuel source for the furnaces and forges. ${ }^{65}$ Oaks were employed in another industrial capacity, as well. In the fifteenth and sixteenth centuries the Basque country was one of Iberia's major shipbuilding centers, providing many of the vessels for Spain's American run, the sixteenth century flotilla of ships that established the Basques as the earliest whalers and codfishermen in Terranova, and the ill-fated Spanish armada. ${ }^{66}$ As early as the fourteenth century the industrial applications of forest products in the Basque country were so extensive that protective legislation had to be instituted to prevent deforestation. ${ }^{67}$

A further graphic indicator of the prominent role of oak trees in Basque awareness is the following list of 104 surnames which incorporate the root aritz: Arisarri, Arisbacochaga, Arizburu, Ariscurrena, Arismendi, Arisnea, Arispe ${ }^{68}$, Arizpe ${ }^{68}$, Arispide, Arispuro, Arisqueta, Arista, Aristabala, Aristain, Aristala, Aristarain, Aristaran, Aristarrazu, Aristaray, Ariste, Aristegui, Aristegueta, Aristeguieta, Aristerrazu, Aristi, Aristia, Aristidi, Aristigaya, Aristiguieta, Aristimuño, Aristisaga, Aristisalazar, Aristizabal, Aristo, Aristondo, Aristorena, Aristoy, Aristrain, Aristu, Arisuria, Arisuro, Arisubiaga, Aritegui, Aritio, Aritzaga, Aritzalde, Aritzandi, Ariz, Ariza, Arizaba,

\footnotetext{
${ }^{64}$ Theodore Lefebvre, Les modes de vie dans les Pyrénées Atlantiques Orientales (Paris: Lib. Armand Colin, 1933), pp. 240-44.

${ }^{65}$ Manuel de Larramendi, Corografía ó descripción general de la muy noble y muy leal Provincia de Guipúzcoa (Barcelona: Imp. de la viuda e hijos de J. Subirana, 1882), p. 77.

${ }^{66}$ For a description of the extraordinary amount of shipbuilding activity in one small Basque port in 1494 (stimulated by the discovery of the New World) cf. Martyr (bishop of Arzendjan), "Relation d'une voyage fait en Europe et dans l'Ocean Atlantique, à la fin du XVe siècle, sous la regne de Charles VIII, par Martyr, évéque d'Arzendjan, dans la grande Armenie, écrite par luimême en armènien, et traduite en français par M. Sain-Martin," Journal Asiatique, 9 (1826), 321-46.

${ }^{67}$ Julio Caro Baroja, Los vascos, 2nd ed. (Madrid: Ed. Minotauro, 1958), p. 233.

${ }^{68}$ Arizpe (Arispe) in Basque means "place of the oak." The present-day Sonoran town of Arizpe is near the site of the original Arizonac. It was founded as a mission in the year 1646 (Diccionario Porrúa, p. 141). Since Arizpe is a common Basque surname it is likely that the town was named for an individual rather than because of the proximity of oak forestation (there would be more colloquial ways in Basque to say "place of the oak"). The propensity to utilize arboreal placenames in the area is not restricted to the Basque possibilities. The town of Nogales (Spanish for walnut trees) is but a short distance from Arizonac, as was the Ranchería Robles (Spanish for oaks) located in the municipality of Caborca (Almada, p. 692).
} 
Arizabal, Arizabala, Arizabalaga, Arizabaleta, Arizabalo, Arizaga, Arizala, Arizalaga, Arizalde, Arizaldebarrena, Arizaldi, Arizaleta, Arizandi, Arizape, Arizarte, Arizburu, Arizcoreta, Arizcorreta, Arizcon, Arizcun, Arizcuren, Arizcuri, Arizcurrena, Arizcurreta, Arizeta, Arizgoiti, Arizgun, Arizmendi, Arizmendiarreta, Ariznabarreta, Ariznavarreta, Ariznoa, Arizola, Arizpeleta, Arizpilleta, Arizqueta, Arizquetacho, Ariztain, Ariztayeta, Ariztegui, Arizteguieta, Arizti, Ariztia, Ariztigaya, Ariztimuño, Ariztinguru, Ariztoi, Ariztondo, Arizu, Arizubiaga, Arizubieta, Arizuleta, Arizuriaga and Arizurieta. ${ }^{69}$

There is another Basque stem for oak which is aretx. So as not to belabor the point I would note simply that López Mendizábal provides 96 other last names employing this form. ${ }^{70}$ Similarly, there are about 40 examples of French Basque surnames employing haritz or haretx. ${ }^{71}$

In sum, there are clear historical and linguistic reasons for believing that Basque is the source of the Arizonac place-name. Whether one accepts the mineral theory (arri or arritz ona) or the arboreal one (aritz $o n a$ ), the phonetic evidence is more persuasive for a Basque rather than Pima-Papago origin.

One point remains-what about the - ac of Arizonac? The only usage of it in the Spanish sources, to my knowledge, is on the 1733 Prudhon map. Anza, as we have seen, a scant four years later refers to "Arissona." Matías de la Mota y Padilla in his Historia de la conquista del reino de la Nueva Galicia, originally published in 1742, uses the form "Arizona." 72 Bancroft, in referring to the question states, "Arizona, probably Arizonac in its original form. .." (emphasis supplied). ${ }^{73}$ Upon what did Bancroft base his speculation? The domain or locational suffix of Pima-Papago (-dag, $-g=-d a k,-k)$ suffix may have been the source. There are numerous examples of Pima-Papago place-names ending thusly (e.g., Bac, Saric), so Bancroft may have been engaging in an inferential exercise. Conversely, he may have had knowledge of concrete employment of the Arizonac form. In any event, Prudhon's usage of Arizonac is the earliest reference to the place-name and it would be telling if Basque failed to accommodate the -ac ending.

\footnotetext{
${ }^{69}$ Issac López Mendizábal, Etimologías de apellidos vascos (Buenos Aires: Lib. del Colégio, 1958), pp. 311-13, passim.

${ }^{70}$ Ibid., pp. 304-8, passim.

${ }^{71}$ lbid., pp. 506-9, passim.

${ }^{72}$ See p. 393 of 1920 edition printed in Guadalajara.

${ }^{73}$ Bancroft, op. cit., p. 520.
} 
This is not, however, the case. In Basque the $-k$ suffix, until recently rendered orthographically as $-c$, is a pluralizer. Reviewing the Basque forms presented above we find that arri onak means "the good or valuable ores," arritza onak means "the good or valuable rocky places" and aritz onak signifies "the good or valuable oaks." Any one of the plural forms can be easily accommodated to the historical and ecological arguments establishing a strong case for a Basque origin of the name of our forty-eighth state.

\section{University of Nevada}

\section{ACKNOWLEDGMENTS}

I wish to thank William H. Jacobsen, Jr. and Peter Comanor for their comments on earlier drafts of this paper. 